\title{
Tabularia
}

\section{The Scripts of Robert of Torigni: Some Notes of Conjectural History}

Les écritures de Robert de Torigni : quelques notes d'une histoire conjecturale Le scritture di Roberto da Torigni : annotazioni di storia congetturale

\section{Thomas N. Bisson}

\section{(2) OpenEdition}

\section{Journals}

Electronic version

URL: https://journals.openedition.org/tabularia/3938

DOI: 10.4000/tabularia.3938

ISSN: $1630-7364$

Publisher:

CRAHAM - Centre Michel de Boüard, Presses universitaires de Caen

Electronic reference

Thomas N. Bisson, "The Scripts of Robert of Torigni: Some Notes of Conjectural History", Tabularia

[Online], Online sources, Online since 16 December 2019, connection on 21 September 2021. URL:

http://journals.openedition.org/tabularia/3938 ; DOI: https://doi.org/10.4000/tabularia.3938

\section{(c) (7) \&}

la revue Tabularia est mise à disposition selon les termes de la Licence Creative Commons Attribution - Pas d'Utilisation Commerciale 4.0 International. 



\title{
The Scripts of Robert of Torigni: Some Notes of Conjectural History
}

\section{Les écritures de Robert de Torigni: quelques notes d'une histoire conjecturale}

\section{Le scritture di Roberto da Torigni: annotazioni di storia congetturale}

\author{
Thomas N. Bisson \\ Professeur émérite d'histoire du Moyen Âge, Harvard University \\ tnbisson@fas.harvard.edu
}

\begin{abstract}
:
This article argues that, while in agreement with B. Pohl that certain annotations in manuscripts of mid s. xii can safely be attributed to the hand of Robert of Torigni (RT), other passages (chiefly in Avranches, Bibliothèque patrimoniale, ms 210, fol. 112v-115r, and in ms 211, fol. 76r) cannot safely be attributed to anyone other than RT, or to a scribe working under his close direction. Moreover, certain markings in rubrics and datings of Leiden ms BPL 20 may be in RT's hand. In addition, I conjecture that the notations .N. and .a. in several manuscripts dating mostly before 1154 were written by RT.
\end{abstract}

Keywords: handwriting, interlinear notations, marginalia, book-lists, interpolations, annals, charters, conjecture, rubrics, paleography, Robert of Torigny, Mont Saint-Michel

\section{Résumé:}

Cet article entend montrer que, bien que B. Pohl ait raison d'attribuer certaines annotations figurant dans des manuscrits normands du milieu du XII siècle à la main de Robert de Torigni (RT), il existe d'autres passages (surtout dans ceux qui sont conservés dans la Bibliothèque patrimoniale d'Avranches, MS 210, fol. 112v-115r, et MS 211, fol. 76r) qui doivent avoir été copiés par RT lui-même ou par la main d'un autre scribe travaillant sous son étroite direction. De plus, certaines annotations dans les rubriques et les dates $d u$ ms Leiden BPL 20 peuvent être attribuées à la main de RT. Et, je soutiens que les notations. N. et .a. qui se trouvent dans quelques manuscrits écrits au Bec, surtout avant 1154, sont de la main de RT.

Mots clés: écriture manuscrite, notations interlinéaires, marginalia, listes de livres, interpolations, annales, chartes, conjectures, rubriques, paléographie, Robert de Torigny, Mont Saint-Michel

\section{Riassunto:}

L'articolo sostiene che, mentre in accordo con B. Pohl che certe annotazioni nei manoscritti di metà s. XII secolo possono essere attribuite alla mano di Roberto di Torigni $(=R T)$, altri passi (principalmente in Avranches, Bibliothèque patrimoniale, $m s$ 210, fol. $112 v-115 r$, e in ms 211, fol. 76r) non possono essere attribuiti a nessuno al di fuori di RT, o a uno scriba che lavorava sotto la sua diretta direzione. Inoltre, alcuni segni nelle rubriche e nelle date del 
manoscritto Leiden ms BPL 20 possono essere scritti dalla mano di RT. Si ipotizza inoltre che le annotazioni.N. e.a. in diversi manoscritti risalenti per lo più prima del 1154 sono state scritte da RT.

Parole chiave: scrittura manoscritta, annotazioni interlineari, marginalia, elenchi di libri, interpolazioni, annali, carte, congetture, rubriche, paleografia, Robert de Torigny, Mont Saint-Michel

In November 2014 a panel convened at my request in the 33rd International Conference of the Haskins Society with the purpose of seeking to identify the scripts of Robert of Torigni, abbot of Le Mont Saint-Michel (1154-1186). The invited panelists were E. M. C. van Houts, Erik Kwakkel, Patricia Stirnemann, and Benjamin Pohl. Their contributions responded to a draft of my own study, with subtitle: "an essay in conjectural history". Dr Pohl had been invited when I learned, belatedly, that he too was working on this subject, and had an article on it in press ${ }^{1}$.

My purpose in this report is not to reproduce my preliminary study of the scripts of Robert of Torigni [hereafter sometimes RT], still less the results of the conference discussion. The circumstances of RT's authorship and handwriting can now be read in Pohl's article ${ }^{2}$, and figure, somewhat differently, in the Introduction to my new edition of the historical writings of Robert of Torigni ${ }^{3}$. As for the session of 2014, readers who did not attend need only be informed that, save on one important point, no consensus emerged. This result was hardly surprising, for what I presented there was a series of conjectural attributions on the basis of sample images shown to experts, only one of whom was currently engaged with the records of Le Mont Saint-Michel.

That a study of the handwriting of a twelfth-century Norman abbot should be worth reading follows from the circumstance that, whereas Robert of Torigni was a considerable personage in his world, the evidence of his life and thought is very incomplete. Well known in the courts of Henry II and Eleanor of Aquitaine, in touch with the crusaders' kingdom of Jerusalem, Sicily, and Spain, with contacts ranging from Germany to England, Ireland, and Scotland, Abbot Robert, for all this, says so little of himself or of his Christian vocation that we cannot know for certain that he was a priest. Yet his footprint on the remembered twelfth century, however dispersed, is sizable; his life and works are of high interest to our knowledge of an age when Benedictine monasticism rose, literally and figuratively, to its heights, while at the same time suffering

1. In addition to scholars mentioned in the first paragraph, and in note 25 below, I wish to thank Stéphane Lecouteux, in his case for help in preparing reproductions from manuscripts in the Bibliothèque patrimoniale d'Avranches, and in much else. My further abbreviation BnF refers to Bibliothèque nationale de France. By "scripts" I refer here to minuscule handwriting in Latin.

2. PoHL, 2014 (see Appendix).

3. The Chronography of Robert of Torigni, T. N. Bisson (ed. and transl.), Oxford, Oxford University Press (Oxford Medieval Texts), 2020, 2 vols. (in press). 
an ominous challenge to its material viability. Learning how Robert of Torigni related to texts and parchments before him may further help us to recognize what he read ${ }^{4}$.

What is offered here is chiefly a précis of my conjectural attributions. These attributions are somewhat altered from those I proposed in 2014; they are better educated in paleography, thanks to Pohl's critique, even as they lead to conclusions at variance with his; and they owe something to what I have learned in working on Robert of Torigni's historical writings. This work has raised a methodological difficulty that needs to be stated at once. The question whether RT wrote Text A or Text B with his own pen may depend on whether Robert was its author as well as its copyist. In at least two instances examined below, it may prove impossible to distinguish sharply between scribe and author writing himself. My findings rest mostly on a study of just over 100 manuscripts of the twelfth century preserved at Avranches ${ }^{5}$; and in present form, they take account of criticisms offered in the panel of 2014. They remain - and I stress this again, as I did in that panel - a set of conjectures. Even on my point of agreement with Dr Pohl, the attribution remains conjectural. Robert of Torigni never (in extant writings) - or just possibly, only once? (see below) - claimed to have inscribed anything. Moreover, my contention that RT not only wrote in the one script that two of us happen to agree must be his own, but in more than one script, will serve as my justification for presenting a revised - yet necessarily provisional - understanding of what and how much we have from RT's own hand in the manuscripts that survive.

Our one point of consensus in 2014 was that many small corrections or précisions between the lines in certain texts are in Robert of Torigni's own hand. My illustrations were drawn from ms Leiden, BPL, 20, which contains RT's edition of William of Jumièges' Gesta Normannorum ducum and other texts; from Avranches MS 159, RT's supervised copy of Eusebius and Sigebert de Gembloux together with his own continuation-chronicle; from ms Avranches, 211, where an early twelfth-century Easter Table bears annotations of RT concerning early abbots of Le Mont Saint-Michel; and from ms Avranches, 146, where a list of twelfth-century popes appears in a script somewhat resembling those in manuscripts just cited. Dr Pohl employs these same illustrations, plus several others, to argue that this angular, "informal", and seemingly irregular script must be that of RT. I am in agreement with him on this point. My plates $1-6 a$ will serve to illustrate it ${ }^{6}$.

4. New work of pertinence and value, since the panel in 2014, is to be found in PoHL and Gathagan, 2018.

5. Bibliothèque patrimoniale d'Avranches, fonds ancien.

6. Showing ms Leiden, Universiteitsbibliotheek, BPL (bibliotheca publica latina), 20, fol. 4r; ms Avranches, Bibl. patrimoniale, 159, fol. 53v; 211, fol. 75v; 146, fol. 165r; 68, fol. ov; 239, fol. 46r. The first of these manuscripts contains an important, if incomplete, copy of a major Norman chronicle which RT himself had edited; the second is RT's own copy of the collection of chronicles to which his own was an addition; the fourth was chiefly a collection of Carolingian capitularies almost certainly compiled before 1154 . 
But this consensus raises difficulties, of at least two kinds. First, it is not always certain that this characteristically angular unflowing writing between the lines is identical with that found free standing in the papal list of Avranches 146 or the book-list in Avranches 68 or in the margins of ms 239. Could it be that Robert of Torigni appears diversely depending on space available to him or on the implement in his hand? How, moreover, can we be sure that this distinctive script was his only attested handwriting? I shall return to this below.

A second difficulty is of a different order. Dr Pohl, both by title and by argument, is bent on discovering the abbot Robert's script: that is, what he inscribed as abbot of Le Mont Saint-Michel. Yet his illustrations (like my own, of this script) come mostly from before his time as abbot. Leiden BPL, 20, even in its composite form, dates from well before 1154 in Le Bec ${ }^{7}$. Only Avranches 159, fols. $1 \mathrm{v}-3 \mathrm{r}$, book-lists of which the first (1v) is not earlier than 1163, appears to form an exception to this pattern; yet while Robert of Torigni could plausibly have worked with one or both of them (as we have them) after 1163, not one of the four marks there identified by Pohl (who cites one only in the long catalogue of Le Bec) looks much like those in earlier manuscripts ${ }^{8}$. As for Pohl's illustrations from BnF latin 6042, all of them antedate 1154; apart from its lists of prelates, assuredly worked over much later at Le Mont Saint-Michel, there is no sign that RT made use of Henry of Huntingdon after about 1150. Most of our examples of interlinear annotation are found in copies of text antedating 1157, and indeed, quite arguably, before RT's move to Le Mont Saint-Michel in mid-1154. Then there is the matter of Avranches 239, a Seneca of mid-twelfth century date. This manuscript may contain our best evidence of Robert's multiple scripts; what it surely displays is the writing, not always between lines, already mentioned (see pl. 6a) ${ }^{9}$. There is reason to conjecture, as I do further below, that RT read and reviewed this manuscript while in Le Bec, before moving to Le Mont Saint-Michel.

Dr Pohl does well in his article to characterize Robert of Torigni's insertions; he shows how they point to Robert's knowledge of elite genealogy and official successions. What he has not noticed is that the annotations in mss 159 and latin 6042 respond very specifically to their circumstances. In both manuscripts RT is not simply correcting, he is "proofreading", as we might say, working in the first case with his copy (now lost) from Sigebert of Gembloux, and in the second case, almost certainly from ms Cambridge Gg II.21, itself the copy made in Le Bec from a (now lost) exemplar of the Historia Anglorum as far as 1146. All the annotations Pohl finds in latin 6042 are omissions RT would have found with Gg II.21 at hand. In support of his view that Abbot Robert worked as corrector in Le Mont Saint-Michel, Pohl cites "three key facts" in its favor: (1) that Paris, BnF, latin 6042 only got to Le Bec in 1163; (2) that Leiden, BPL,

7. On this point, see below, note 13 .

8. Ms Avranches, Bibl. patrimoniale, 159, fols. 1v, 2va-3r; PoHL, 2014, pp. 56-57. Both lists were entitled Tituli librorum [...], probably by RT himself when he inserted them in ms 159 on a late date in its preparation; often printed, they are re-edited by CLEAVER, 2018, p. 190-205.

9. Ms Avranches, Bibl. patrimoniale, 239, fols. 45v, 46r, 56v, 66r, 76r. 
20 cannot have been amended by RT before 1163 , for only then or later were all three parts bearing RT's annotations bound together; and (3) that Avranches 159 contains only what RT wrote after arriving at the Mount ${ }^{10}$.

Not one of these propositions holds up under scrutiny. The $H A$ in Paris, $\mathrm{BnF}$, latin 6042 was almost certainly in Robert's hands before or soon after he arrived in Le Mont Saint-Michel, even if works on its appended lists came later; it seems to be a copy of Cambridge Gg II.21, made in Le Bec. As for Leiden, BPL, 20 , this manuscript is not listed in the catalogue of Bishop Philip's bequest, as Pohl claims elsewhere ${ }^{11}$; on the contrary, it figures only in the long catalogue of the library of Le Bec, almost certainly compiled by RT before he left Le Bec ${ }^{12}$. With respect to MS 159, all we can know for sure is that its copy of Eusebius and Sigebert was in near final form in at least two other manuscripts before $1154^{13}$; so that while RT wished for his latest copy to be correct and updated, quite surely his work as corrector was all but complete before he left Le Bec. New work at the Mount left him little time for such review. And what is certain is that in ms 159 no folio of his annals still in progress after 1161 bears witness to this corrector's eye.

Returning now to the problem whether the distinctive script already identified adequately represents the Robert of Torigni we know from the manuscripts. What relates to him otherwise points to a puzzle. From much evidence we know him to have been a consummately literate monk. As a young Benedictine he lost no time reading his way into the rich Beccan past. Still in his twenties he teamed with Orderic Vitalis to reedit the Gesta Normannorum ducum, to which he added a wholly original new book on King Henry I. Become bibliographer and librarian in the 1140s, he was chosen prior of Le Bec in 1149, still young, and with further promotion soon to come. Perhaps in this context we can begin to grasp why evidence of his handwriting seems so limited. For already before he began to turn his interpolations in other chronicles into annals of his own, he had learned how to rely on other scribes to make presentable copies of his and others' works. Moreover, it looks as if, quite possibly, the very manuscripts most likely to have borne RT's lettering were not simply lost early, but - like his draft-annals - were deliberately destroyed when superseded.

Arguably, in this perspective, only two such manuscripts survive. One of these is Leiden BPL, 20, which has long seemed to scholars to bear traces of Robert of Torigni's handwriting. Does it, in fact, reveal anything from his pen other than the annotations already mentioned? Before facing this question (to which I return below), let me cite a second original manuscript that has been central in past efforts to discern RT's writing. The Easter Table in Avranches 211 not only contains annals bearing RT's annotations (plate 3) - these, I believe, were written after RT's discovery of the annals of Le Mont Saint-Michel upon

\footnotetext{
10. POHL, 2014, p. 70.

11. POHL, 2015, p. 161

12. It is important to understand in this connection that these catalogues, attached to ms 159 perhaps well after 1163 , are in distinct hands and were originally written on separate sheets.

13. Namely, the exemplars from which BnF latin 4862 and BL Arundel 18 were created.
} 
first arrival at the Mount -; it also contains a fresh set of near current annals in a distinctively fluid hand running from AD 1134 to 1173 (plate 7; cf. pl. 3) ${ }^{14}$. That RT composed these annals - surely all at once, about 1173 - seems highly probable. For (at AD 1163) he says that he did: "we who have written these things [qui hec scripsimus]". Does his verb scribere mean that he not only composed, but also penned these annals? That he could indeed have done both - or have added entries himself - is suggested by one further consideration: namely, that these annals in both margins are so exactly pegged to their A.D. numerals that it is difficult to imagine anyone other than their author writing them here ${ }^{15}$.

These annals, when taken together with those in another manuscript, raise a quite different possibility for consideration. Just as, in ms 211, Robert of Torigni inserted annals in close correspondence with his template of year-dates, so too in ms Avranches, Bibl. patrimoniale, 210, fol. 114r, RT records the lord-king Henry's grant to the monks of the Mount of a charter of remedy, doing so as if he himself (Robert) were writing both the royal charter and the present record of its grant (plate 8) ${ }^{16}$. Now, as it happens, the paleographers who studied these two manuscripts in 1984 opined that in both manuscripts the places in question are in the handwriting of Robert of Torigni ${ }^{17}$. Is it not possible, or even likely, that in cases of his own composition, written in constraints of space, RT sometimes inscribed himself, or else directed the writing over a scribe's shoulder? The two scripts just mentioned do not look alike to me; what they do have in common is the circumstance that $\mathrm{RT}$ was as close to their writing as to their composition.

Returning to the annals in ms 211, fol. 76r, Benjamin Pohl may be justified in rejecting the attribution of their script to Robert of Torigni. I am hesitant myself, proposing as I do just above. But his rejection like my hesitation must be recognized for what they are: problematic conjectures by two modern readers. For there are samples of annotation in other manuscripts that resemble this (second) script in Avranches 211 nearly enough - and in likely places, such as $\mathrm{ms} 210$ and one or two of the book lists promoted by RT - to pose the question whether Robert wrote in scripts other than the one that Pohl attributes to him. I cited and illustrated several such samples in 2014, and do so again here (plates 9 , 10 ${ }^{18}$. Nevertheless, these very plates also display coarse scripts resembling those more safely attributed to RT; and so too, quite remarkably, does the book-list prefixed to ms Avranches, Bibl. patrimoniale, 68 (plate 5; cf. pls. 1, 3, 4), which (here in agreement with Dr Pohl) I would tentatively ascribe to RT. This is the place to suggest, however, that this avenue of research is premature. We still do not know which or how many of the hundred or so manuscripts labeled

14. Ms Avranches, Bibl. patrimoniale, 211, fols. 75v-76r. On the discovery of annals in 1154, see Lecouteux, 2018, pp. 6-15.

15. POHL, 2014, pp. 71-72, note 24, questions the ascription of these marginal annals to a single scribe, while discerning one group of entries that could have been added by RT.

16. This entry occurs in a text that I refer to as "annuary", of which a new edition appears in Chronography of Robert of Torigni, vol. 2, text IV.

17. Garand, Grand et Muzerelle, 1984, p. 77 (both manuscripts).

18. See mss Avranches, Bibl. patrimoniale, 210, fol. 118r; 241, fol. 66v; 84, fol. 1v. 
"twelfth-century" in the Fonds Ancien of Avranches antedate Robert of Torigni. A counting of the scribes he assembled about him, in paleographical research such as Teresa Webber lavished on Salisbury ${ }^{19}$, will be required to clarify the surviving extent of RT's traces. But my own sounding in the copies of St Augustine there preserved suffices to show that, while I was mistaken to discern Robert's hand in an addition to the book-list prefixed to ms 84 (fol. 1v, pl. 10), I can now safely conclude that it was Robert's appointed scribe who penned this addition to a book-list composed in the time of Abbot Bernard; and further, that the original list together with the copied text that follows is in the same hand of Bernard's scribe. RT's scribe in ms 84 can also be found in book-lists inserted in mss 88, 92, and 93, all of which are copies of Augustine made in the time of Abbot Bernard (1131-1149).

There remain two further lines of conjecture relating to reader's marks and rubrics attributable to Robert of Torigni. Neither one elicited critical response when I introduced them in 2014, yet both remain central to the question of Robert of Torigni as scribe. If we know too little about how his writings got from draft to expert copy, we know still less about RT the reader. Yet that may be because we have overlooked one precious clue in the margins of manuscripts. The matter of rubrics is differently problematic, if hardly less in need of study.

Scattered through the extant manuscripts that can be associated with Robert of Torigni, including most of those cited above, are the marginal annotations .N. and .a. The first of these, alone, is both more common and more distinctive, but the two marks often appear in tandem in margins. As elsewhere, these notes appear to be abbreviations for the imperatives nota (that is, take note, or note here) and adtende (or attende, note with special care); but what matters first is how familiar they look to anyone who has handled the manuscripts of Le Bec and Le Mont Saint-Michel. Moreover, the incidence of these marginalia happens to coincide with the adjusted chronology I have proposed above. The earliest known manuscript of RT (Leiden, BPL, 20) is filled with these marks, fols. $4 \mathrm{r}$ (plate 1), $5 \mathrm{r}$, $8 \mathrm{r}$, as is the copy of Einhard (e.g., fols. 33rb-34va) which follows that of William of Jumièges. Precisely the same abbreviations clutter the margins of Cambridge Gg II.21, the copy of Henry of Huntingdon also made in Le Bec in the $114 \mathrm{os}^{20}$. My apparatus to his chronicle will show that Robert drew on this manuscript for his borrowings, as well as on Paris, BnF, latin 6042. The latter likewise has these marks, perhaps there, in the annotation .a., a sign (and not the only sign) that this manuscript, too, antedates $1154^{21}$. And in Avranches, 159, fol. 53v (plate 2), the familiar marginal .N. appears exactly where RT's first interpolation in the Eusebian prefix to Sigebert's chronicle has been entered ${ }^{22}$; it then appears some

19. WeBber, 1992.

20. E.g., fols. $4 \mathrm{~V}, 5 \mathrm{r}, 5 \mathrm{v}, 6 \mathrm{r}, 6 \mathrm{v}, 8 \mathrm{v}, 10 \mathrm{r}, 85 \mathrm{v}$.

21. Apart from lists prefixed and added later, the latest dateable content in this manuscript is a record of the legatine council of London, 18 March 1151, fol. 121.

22. The same mark had been entered already on fols. $8 \mathrm{r}, 37 \mathrm{r}, 39 \mathrm{v}, 41 \mathrm{r}$, and $49 \mathrm{v}$, all places of demonstrable interest to one writing history. As in other manuscripts, these annotations, in a consistent distinct hand, accompany text in which RT has also inscribed verbal adjustments. 
thirty-five times in the annals down to 1137, - and no further. The .a., although far less frequent, seems associated with matters of notable importance, including the late insertion of an entry on Gratian $(1130)^{23}$. Nor is this all. Both the Seneca of Avranches 239 (plates 6a, 6b) and the GND in BnF latin 5997A - the latter probably copied from Leiden, BPL, 20, surely in Le $\mathrm{Bec}^{24}$ - have the same marginalia, the Seneca in profusion. This fact, while hardly decisive in itself, is probably, in its context, another pointer to the existence and use of these manuscripts before 1154. The annotator(s) may have been drawing on tradition at Le Bec, where the marginal .a. is famously attested in the Collectio Lanfranci preserved in ms Cambridge, Trinity College, B.16.44 ${ }^{25}$.

From this evidence, one considerable conjecture follows. Someone, quite probably a monk of Le Bec, was annotating the very historical manuscripts we know to be most closely associated with Robert of Torigni. Never does he identify himself. But why should he do so? And whom should we imagine, other than $\mathrm{RT}$, who was so engaged with history in Le Bec towards 1130-1150? If the newly avowed Robert had a mentor-monk, such as John of Reims to Orderic Vitalis, his identity eludes us. In short, while the evidence that RT was usually (mostly, normally) the reader who marked these historical manuscripts is conjectural, it is strong and uncontested.

Yet this finding, limited though it is, needs to be qualified with care. As in scriptoria elsewhere, it is unsafe to assume that all such annotations, even those apparently identical, were written in a same hand. But if imitation there was - that is, some effort to reproduce the forms of lettering -, it must often have been purposive, as if someone else were there to lead the way. In only one instance, perhaps the very earliest one, can I discern the nota in the hand of an associated text; and in this single case, the hand in question may be that of the one who is correcting text - almost certainly Robert of Torigni himself ${ }^{26}$. Moreover, the pattern of pertinent citations, notably perceptible in ms 159, conforms better with what we know of the monk-historian Robert than with what we might imagine of a directed scribe. One important reason for supposing that RT was the usual writer of .N. and .a. in the margins of his manuscripts lies in the circumstance that these annotations appear characteristically alike in whatever manuscript they appear. They seldom match the copyist's script. This is evident in ms 159, fol. 53v (plate 2), where we may have RT's words in two distinct scripts (left margin, and see also line 7 down) and/or different pens; but the same point can be verified in almost every manuscript where these annotations appear: in the Leiden GND, the Avranches Seneca, and in both

23. For the consistently formed .a., see ms Avranches, Bibl. patrimoniale, 159, fols. 145V, 154V, 183r, $191 \mathrm{r}(1130)$.

24. Hermans and van Houts, 1982, pp. 79-94, 219-226, at 79.

25. BROOKE, 1989, pp. 65-70; see also GULLICK, 2008, pp. 79-89. For guidance on this point, I thank Teresa Webber and Evina Steinová. The .N. and .a. also figure, in a more elaborate array of signs, in manuscripts of Gembloux: see BABCOCK and DeroleZ, 2015, at p. 264.

26. Ms Leiden, Universiteitsbibliotheek, BPL, 20, fol. 2r; see also fols. 3v, 4r, 4v. 
Beccan copies of Henry of Huntingdon ${ }^{27}$. What is more, the point is evident, if not exactly verified, in a copyist's visible imitation of RT's annotations .N. and .a. in a florilegium created by Stephen of Rouen in honor of Waleran of Meulan towards $116 \mathrm{o}^{28}$. And there is nothing in the records of Le Mont SaintMichel post-dating 1154 to refute it.

Nor is there much, however, to sustain this sense of engagement with manuscripts, apart from the book-lists, which point to Abbot Robert's wider readings. As noticed above, he became concerned with older manuscripts to be found in or brought to the Mount. Ms Avranches 88 is an aggregate of Augustinian opuscula, the copy mostly dating from the abbacy of Bernard, yet quite surely handled by Robert of Torigni, if not in this instance by his own scribe $^{29}$. Diverse traces of his interests seem discernible in a book of histories in distinct existing manuscripts stitched together ( $\mathrm{ms} \mathrm{162}$ ), and in a copy of Cicero's De officiis (ms 225) ${ }^{30}$. But two changes now become perceptible. First, Robert of Torigni's own annotations, to judge by comparison with those made when he was at Le Bec, diminish in number, even as his manuscripts produced in the Mount multiply. They are mostly lacking in three historical manuscripts of these years ${ }^{31}$. Second, the annotations.N. and .a. begin to appear in visibly different or distinct forms or hands ${ }^{32}$, which is not, to be sure, proof of other authorship. These changes coincide with the multiplication of content lists in diverse hands. Abbot Robert's engagement with books continued, as we shall see; his need of the moral wisdom he found in saints Augustine and Gregory was never greater. But he now had literate monks at his side, ready to share in his anonymous bibliography, writing, and copying. One of them, in all probability, penned the explanatory preface in which RT introduces the lists of bishops that were attached to his second copy of Henry of Huntingdon ${ }^{33}$.

It becomes clear that little survives of extended writings, by anyone, in Robert of Torigni's own hand. In a way, this is proof of the importance of a revived scriptorium in the Mount ${ }^{34}$. Several expert scripts can be recognized in the manuscripts copied at Le Mont Saint-Michel after 1154, including the

27. Ms Leiden, Universiteitsbibliotheek, BPL, 20, fol. 8r, 9r; ms Avranches, Bibl. patrimoniale, 239, fol. 17r, 24r, 36v; ms Cambridge University Library, Gg II.21, fols. 14r, 15r, 45v, 47v; ms Paris, BnF, lat. 6042 , fols. 22 r, 24r, 67v, 89v; ms lat. 5997A, fols. 1v, 3r; ms lat. 14146, fols. $163 \mathrm{r}, 167 \mathrm{v}$.

28. Ms Paris, BnF, lat. 14146 , fols. $163 \mathrm{r}-170 \mathrm{v}$. The original quire, containing a copy of popes' and prelates' letters, was surely in Robert's hands around 1148-1150 when he cited a letter of Archbishop Hugh of Rouen (1129-1164), here fol. 167v, in his annal for 1145 (Chronography of Robert of Torigni, vol. 1, p. 142).

29. Fols. 2v-3r.

30. Ms 162, fol. 2rb; ms 225, fol. 49r, where RT, quite surely he, glosses Cicero's title "scilicet disputationum".

31. Mss Avranches, Bibl. patrimoniale, 157, 160, 162.

32. Mss Avranches, Bibl. patrimoniale, 225, fol. 49v; 230, fol. 9rb; 242, fol. 73r; compare also ms 113, fol. 2 or (are these RT's annotations, made in Le Bec?).

33. Ms Paris, BnF, lat. 6042, fol. 1r (The Chronography of Robert of Torigni, vol. 2, Text VI C).

34. On which, see Nortier, 1966, p. 135-152, together with BourgeoIs-LeCHARTIER, 1967, p. 171-175, and plates I-XVI. 
exceptional two in mss 210 (dating to 1157) and 211 (c. 1173) that have been attributed to RT. There was little reason to retain superseded drafts, if not for fuel. Nevertheless, it remains to notice that in one respect RT was and, even as abbot, remained demonstrably engaged with the manuscripts he viewed, read, or carried forward. He cared about their appearance. And this means that he cared about rubrics quite specially: that is, not merely with book- and chapter-titles and with incipits and explicits, but also with the numberings of books and chapters.

To judge from the two records Robert of Torigni is known to have supervised, ms Leiden BPL 20 and ms Avranches 159, this engagement can be recognized with some precision. The first of these conveys his own edition of William of Jumièges, beginning (as we have it, the prior text is lost) with Book 5 (as renumbered by RT) chapter 3. This means that the extant manuscript contains the sutures between Books 5 and 6, 6 and 7, 7 and 8 (fols. 5r, 9v, 21v). In these three places Robert's lists of chapters to follow were listed, by different scribes, in the spaces left blank for this purpose. Probably this work followed closely on the copying of texts, for there is little sign of spatial miscalculation. But what is certain is that the re-numbering of books - five to four, fol. 5r; six to five, fol. 9v; seven to six, fol. 21v - had not been entered when RT's new Book 8, on Henry I, was copied, following twelve vacant lines, on a new folio (22v). For the rubric had opened "Incipit liber .viii." before its scribe caught the slip, and rewrote ".vii." (as he then continued to do; pl. 11). There is no sign of such correction in the three prior sutures mentioned above. Conceivably, this was a belated error; but the more likely explanation is that the prior sutures had not yet been rubricated. And what renders this explanation likely is that the explicits and incipits in all three of the prior connecting passages appear to have been added, or squeezed into their places. Moreover, it looks as if, throughout, the (roman) numbering of chapters, both in capitula and in text, has been added. What all this suggests is that the articulation of RT's expanded Gesta Normannorum ducum in ms Leiden, BPL, 20 was carried out in two stages: first, the copy of text with RT's new chaptering, followed, secondly, by the insertions explicit, incipit, and numbers. In the second stage, RT was close at hand, if not even himself entering the numerals.

A comparable scenario can be found in ms Avranches 159. In its two parts - a corrected final version of Robert's chronicle to 1157 , and its continuation to 1184 -it has something to teach us about rubrics, while illustrating much else argued in this article. RT evidently thought of his chronicle as complete in 1157, but not for itself alone. What he must already have prized was his own part in a prestigious "history-book", comprising the world history of Sigebert of Gembloux as produced by the latter: that is, beginning with Eusebius of Caesarea's Chronological Tables in Jerome's translation, continued by Jerome past A.D. 328 to 379, then by (so Sigebert thought) Prosper of Aquitaine for another century, followed by Sigebert's own "chronography" beginning (again) at $381^{35}$. The links between these books, and sometimes their prologues,

35. On Sigebert's enterprise, see Chazan, 1999. 
required rubric headlines, which as a rule $\mathrm{RT}$ and his scribes simply copied from their exemplar of Sigebert.

Now while this exemplar is lost, we have the good fortune of possessing its parent, the grandfather of $\mathrm{ms} 159^{36}$. And this means that we can reconstruct the lost parent; indeed, quite precisely so, for the singular reason that Robert's new book of 1157 was, for some of its extent, an exact replica (at one remove) of its grandparent. So whether RT himself or, more likely, some other scribe copied rubrics into the cluttered manuscript that ms 159 superseded, we can discern just where he reproduced Sigebert's rubrics, and when and why he departed from them. In Eusebius, for example, he reproduced Sigebert's headline and incipits unchanged, save for a more elaborate decoration such as persists throughout. On the other hand, because the copyist of Sigebert at Beauvais had failed to mark off his hucusque clause in red, it looks as if RT was the one who did so, and who then directed his scribe to insert a new rubric "Explicit chronica eusebii. Incipit chronica ieronimi". The first of these changes had already been made in the exemplars of British Library MS Arundel 18, and of ms Paris, BnF, latin 4862; the quoted rubric was new as we have it in ms 159, entered some time after 1157 when this manuscript was still in preparation for presentation. At fol. 66r the hucusque clause between Jerome and pseudo-Prosper is fully copied (at second hand) from the Beauvais Sigebert in the principal scribe's hand. In this case, comparison shows that the scribe of A was in exact conformity with the texts of Beauvais and (as we have it) Savigny, while diverging somewhat from that in Arundel 18. In this place, as in others, the latter seems to preserve a variant, perhaps experimental, copy of Sigebert that was to be abandoned.

Most illuminating of these instances is the next suture, which takes the reader from Prosper to Sigebert. In ms 159, fol. 69vb, Sigebert's lengthy hucusque is fully entered by the current scribe (of text), leaving the last nine lines blank, exactly as in the Beauvais exemplar (fol. $67 \mathrm{v}$ ). And in this space a subsequent hand - surely the same second hand as in fol. 61v, Robert's scribe (if not RT himself) - has composed and entered a new incipit, perfectly filling the empty space to its limit, and incidentally detailing the chronological understanding of his own place in the composite book. And then, two folios further on, RT seems to have spotted the omission of the explicit-incipit preceding Sigebert's own text, and to have entered a neatly abbreviated version of it so as to fill the available space, once again in a distinct subsequent hand.

What this evidence shows is that, for matters down to the ninth century, Sigebert's compilation held up on its own. Robert of Torigni edited, adjusted, but did little more. But once his interpolations from the Annals of Rouen, William of Jumièges, and Henry of Huntingdon began to multiply, including some not yet integrated in the lost copy from Robert's exemplar, it became impossible to retain absolute fidelity of format to the original Sigebert in the Beauvais copy. In this perspective RT's interpolation, recopied in red, of a new annal, telling of

36. Ms Paris, BnF, lat. 17545 . 
the installation of Benedictine monks in Le Mont Saint-Michel in 966, marks the initiation of his own continuation-chronicle. This rubric had been entered, probably by RT himself (for it sounds like him), in the lost alpha; it figures in ms 159 in what looks like the main scribe's hand ${ }^{37}$. A rubric at A.D. 978 copied from Sigebert-alpha is surely the same scribe's work ${ }^{38}$. There follow twelve further rubrics in MS 159, all composed by RT; and three or four of these were visibly entered by the scribe who was copying alpha towards $1156-57^{39}$. The other eight exhibit Abbot Robert many years later, directing another scribe, correcting and adjusting as then necessary. Two or three of these may be in Robert's very hand, those at fol. $18 \mathrm{ov}$ seeming to imitate (or prescribe) the desired ordinatio ${ }^{40}$. One of these places merits further notice. At fol. 17ov the principal scribe had entered a headline rubric for RT's tract on the Norman monasteries, exactly where this was placed in the manuscript of 1157 . But by the time of his later review - in fact, probably rather earlier than that - Abbot Robert had changed his mind, wishing that this extraneous text not interrupt the sequence of prologue and now-extended annals; that it be an appendix. His marginal rubric to this effect was surely composed by him, and entered, in Robert's presence, by the same scribe who had lately reviewed throughout (plate 12) ${ }^{41}$.

In light of these findings, I am led to think differently about the subject of this article. It no longer surprises me that past scholars were disposed to seek Robert of Torigni in the scripts of his manuscripts. Ludwig Conrad Bethmann, in his fundamental edition of Sigebert of Gembloux and its continuations, declared that Avranches MS 159 was Robert's "autograph copy" for the years 1156 to 1185; this even as he recognized the "highest variety" in the many scripts he discerned there ${ }^{42}$. Léopold Delisle, far more cautious, wrote simply in reference to these same later folios in ms 159: "Nous avons bien sous les yeux un manuscrit original et dont certains morceaux sont peut-être autographes" ${ }^{3}$. Richard Howlett tended to agree with Delisle, yet he asserted firmly that RT was the scribe who wrote (in ms 159) fol. 216v, as well as ms 210, fol. 112v-115r (the annuary) ${ }^{44}$. Benjamin Pohl

37. Ms 159, fol. 141r. It had been prescribed in the margin above, surely on RT's instruction.

38. Ms 159, fol. 143v.

39. Ms 159 , fols. $144 \mathrm{r}, 164 \mathrm{r}, 168 \mathrm{v}, 169 \mathrm{r}, 17 \mathrm{ov}, 174 \mathrm{v}, 178 \mathrm{v}, 18 \mathrm{or}, 18 \mathrm{ov}, 228 \mathrm{v}, 229 \mathrm{r}, 231 \mathrm{r}$. The prior rubrics are at fols. 144r, 169r, 170v, 174v. RT's use of Sigebert's rubrics ends here. A long rubric about Sigebert, lately deceased, was entered in ms Paris, BnF, lat. 17545 (fol. 154r); it became a source for RT in the exemplar of lat. 4862 (fol. 124vb), but was thereafter disused.

40. See also ms 159 , fols. $178 \mathrm{v}, 18$ or.

41. Ms 159, fol. $170 v$.

42. Sigeberti Gemblacensis chronographia, ed. L. C. Bethmann, Hanover, Hahn (Monumenta Germaniae historica, Scriptores vi), 1844, pp. 268-374, at 294

43. DeLISLE, 1872-1873, vol. 1, p. li.

44. Howlett, Richard (ed.), "The Chronicle of Robert of Torigni, Abbot of the Monastery of St. Michael-in-Peril-of-the-Sea", in Chronicles of the Reigns of Stephen, Henry II, and Richard I, Vol. IV, London, Eyre and Spottiswoode (Rerum britannicarum medii aevi scriptores, 82), 1889, pp. xvi, lxi. With respect to ms 210, he anticipated the finding of the French paleographers Garand, Grand, and Muzerelle, cited above, note 16. 
has rejected nearly all such attributions, stressing the importance of copyists' work under Robert of Torigni, while allowing only for certain annotations, mostly interlinear, in several manuscripts prior to $1161^{45}$.

Yet this last opinion, based though it is on rigorous paleography, may itself underrate the circumstance that explains why many readers, myself included, have sought to identify the handwriting of Robert of Torigni. In pages above I have cited some places where Robert seems "close" to the writing: the second annals in ms Avranches, MS 211, fol. 76r; the "annuary" (1155-59) in ms 210, fols. 112v-115r; and some late rubrics in ms 159 . These places stand in contrast with others - the Tituli librorum Beccensis almarii (ms 159, fols. 2r-3r; the contents-page in ms 159, fol. 3v), etc. - where Robert's impersonal verbiage is being set down by his scribes. It is a question of authorial proximity to the writing, which can vary. In the places cited from mss 211 and 210 one senses RT so attentive to the handwriting that these different scripts are virtually his own. And because, from much other evidence, it is clear that Robert deliberately relied on scribes other than himself to transcribe from exemplars and to prepare presentation-copies of texts, including those of his own composition, a holistic scenario is revealed that must allow for Robert of Torigni intervening - more or less - in scribal work.

This would have occurred when copying proceeded by stages. There were at least two such stages in the preparation of Leiden, BPL, 20; perhaps three in that of Avranches ms 159. Like Bethmann before him, Delisle had in mind the irregularities of script visible in the later folios of ms 159 when he opined that "certain passages are perhaps autograph" ${ }^{46}$. Yet the same scenario seems discernible in a partial copy of Abbot Robert's chronicle made in Le Mont Saint-Michel by a single scribe under Robert's direction ${ }^{47}$. Some erratic writing towards the end as well as minor departures from his known source may include touches by RT himself; and it cannot be ruled out, on present evidence, that the misaddressed covering-letter accidentally attached to these quires sent to Le Bec is in the script of Robert of Torigni ${ }^{48}$. And besides all this, the marginal annotations .N. and .a. in some earlier manuscripts point very specifically to a variant script associated with the monk Robert's reading.

In the present state of our knowledge, it seems fair to conclude that Robert of Torigni wrote in variable scripts, at least one of which - and perhaps two, counting the reader's marks - has/have been identified, while others remain to be recognized. They will stand out clearly only when further study of the

45. PoHL, 2014 as cited above, note 2 and further notes. See also above, at note 15.

46. See note 43 above.

47. Ms London, British Library, Cotton Domitian A viii, fols. 71r-94v, fully described in The Chronography of Robert of Torigni, vol. 1, pp. lxviii-lxvix. Howlett, as cited in note 44 above, and at his p. liv, would surely have discerned traces of RT's hand in this manuscript if he had known where it was made.

48. Bethmann was unaware, Sigeberti Gemblacensis chronographia, p. 295, that these quires were produced in Le Mont Saint-Michel. The matter is examined in The Chronography of Robert of Torigni, vol. 1, pp. xcii-xciii. 
manuscripts of Le Mont Saint-Michel is carried out. And it is as monk of Le Bec, not as abbot of Le Mont Saint-Michel, that RT's writing in pen and ink is chiefly known to us. This could have been by design, for if the scripts in the annuary of 1157 and the annals of 1173 are not to be ascribed to RT, their very quality lends support to a further conclusion. For his own writings Robert of Torigni relied on his expert scribes, perhaps more numerous than ever after 1154, to produce final copies.

\section{Appendix}

The pages above cannot be reduced to a list of secure attributions of handwriting, such as B. Pohl appended to "The Handwriting of Robert of Torigni" ${ }^{4}$. Those attributions, as stated above, seem justified to me. The present study, while mostly accepting Pohl's findings, departs from them on three points: (1) the chronology of Robert of Torigni's annotations in Leiden, BPL, 20; mss Avranches, Bibl. patrimoniale, 239 and (mostly) 159, which I would date before 1154, not to Robert's time as abbot; (2) the possibility that RT intervened in the writing of ms Avranches, 210, fol. 114r; and (3) the tentative attribution of certain annotations .N. and .a. to Robert of Torigni. These annotations appear in Leiden, BPL, 20; Avranches 88, 159, 239; Cambridge University Library MS Gg II.21; ms Paris, BnF, lat. 5997A, 2042, 14146. How nearly complete is this list will only become known if paleographers take my tentative attributions of these annotations seriously enough to subject them to the close study they deserve. The matter is complicated by the possibility that RT himself entered these annotations in varied forms. What can be said here already is that the lettered form of these marks I attribute to Robert is found in items 1, 2, 3, and 5 of Pohl's list, that is, in the very manuscripts where RT's hand is otherwise attested.

49. POHL, 2014, p. 82.

URL: http://journals.openedition.org/tabularia/3938 | DOI : 10.4000/tabularia.3938 


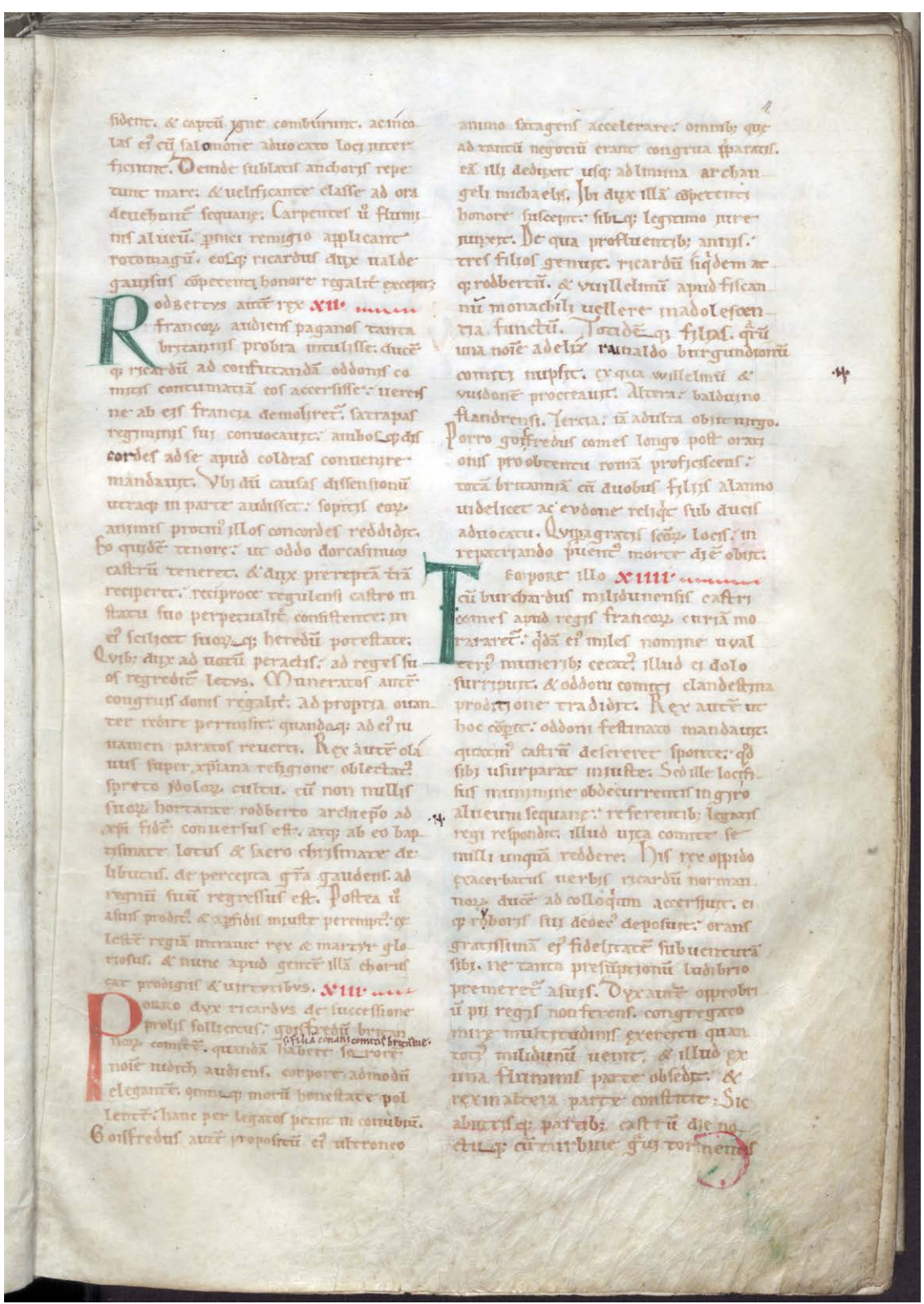

Pl. 1: Leiden, Universiteitsbibliotheek, ms. BPL 20, fol. $4 \mathrm{r}$ 


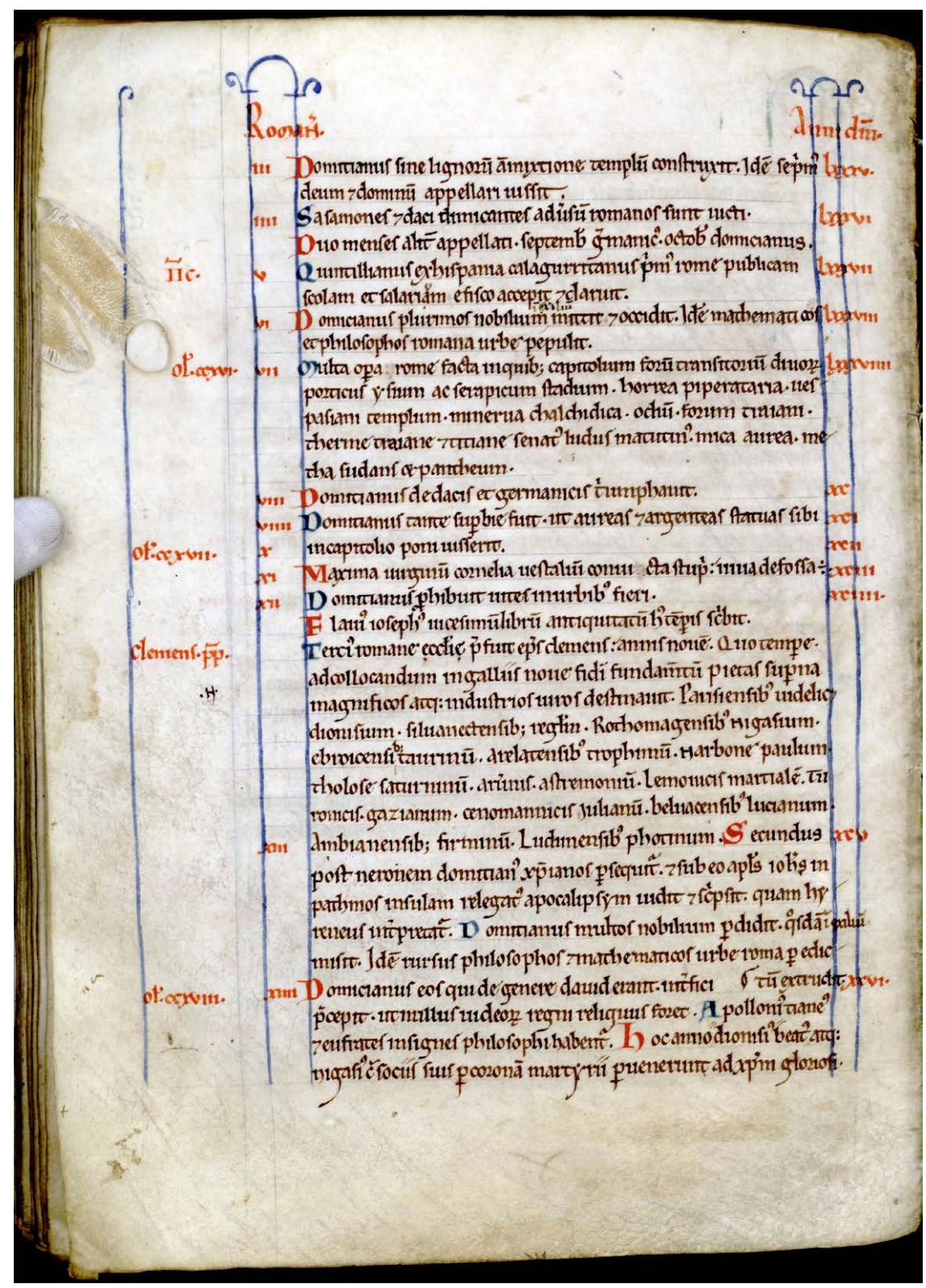

Pl. 2: Avranches, Bibliothèque patrimoniale, ms. 159, fol. 53V 


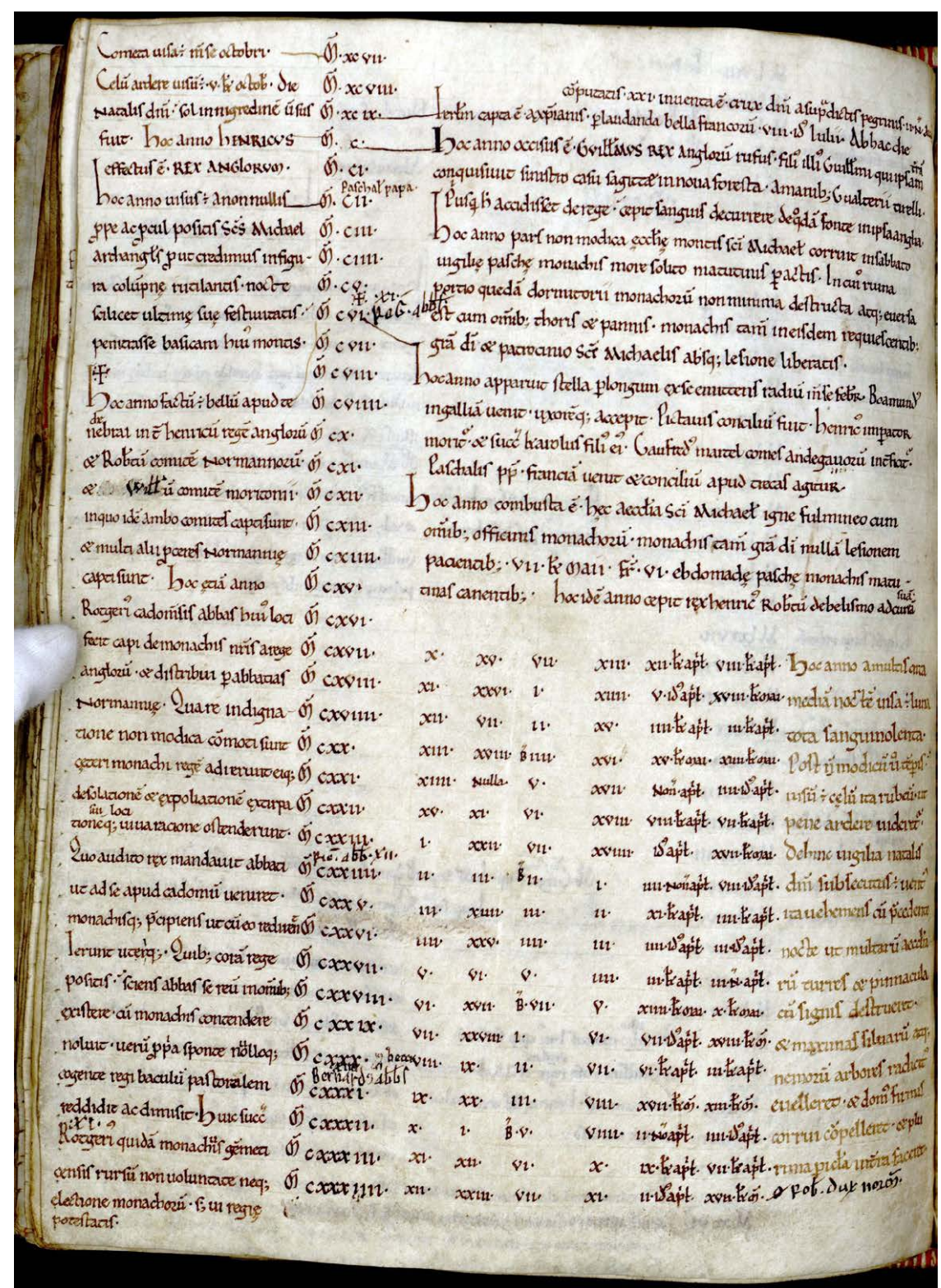

Pl. 3: Avranches, Bibliothèque patrimoniale, ms. 211, fol. $75 \mathrm{~V}$ 


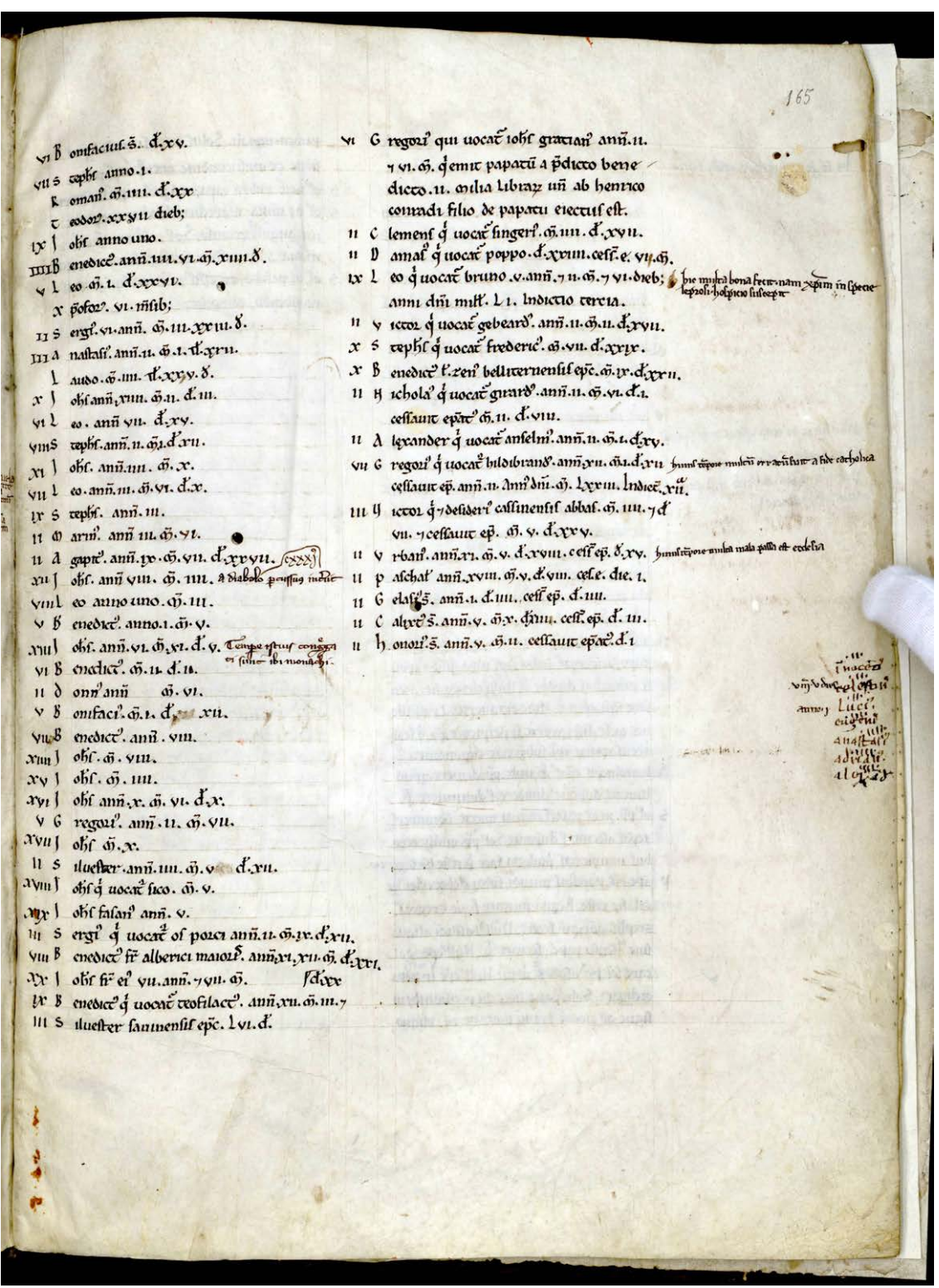

Pl. 4: Avranches, Bibliothèque patrimoniale, ms. 146, fol. 165r 


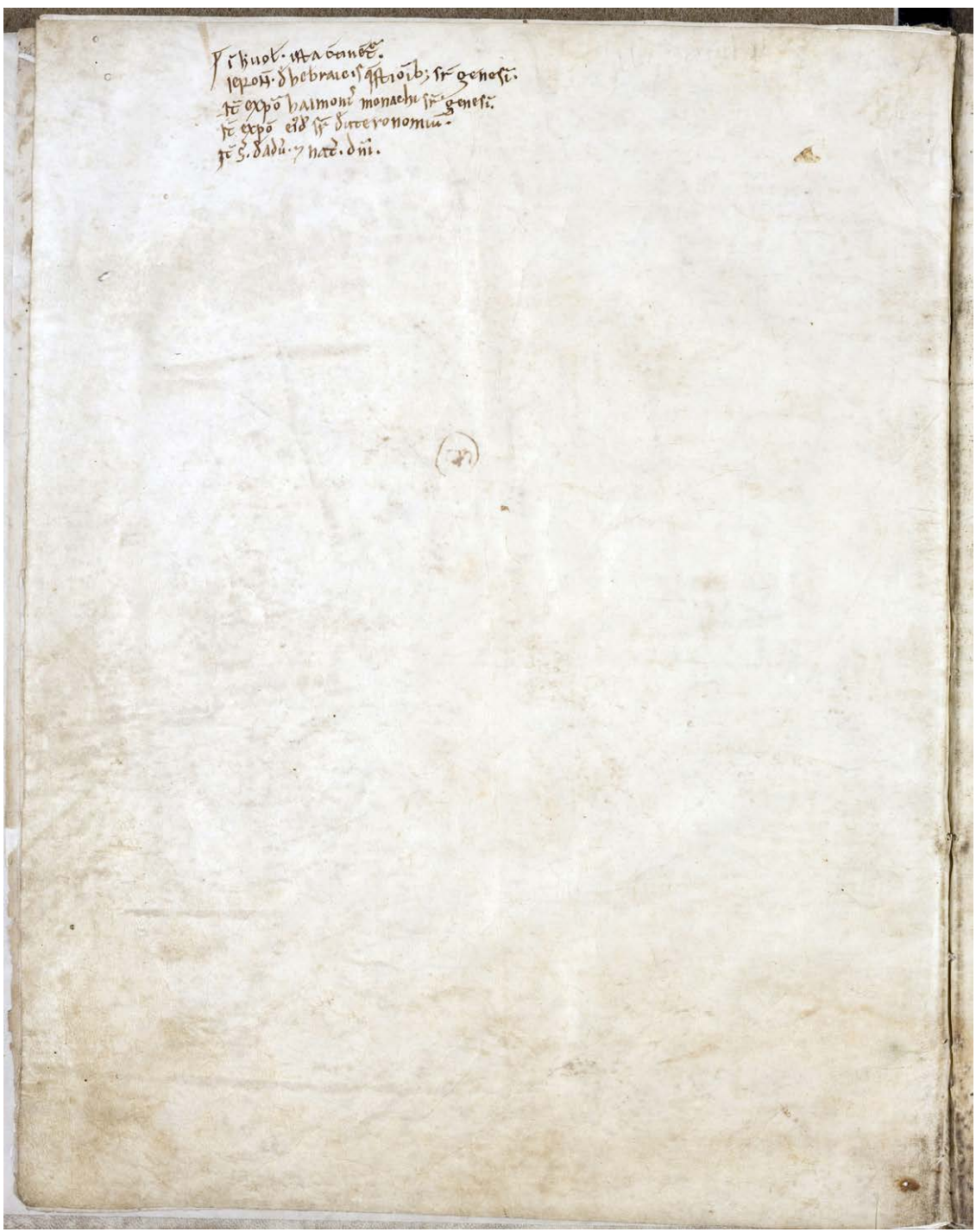

Pl. 5: Avranches, Bibliothèque patrimoniale, ms. 68, fol. Av 


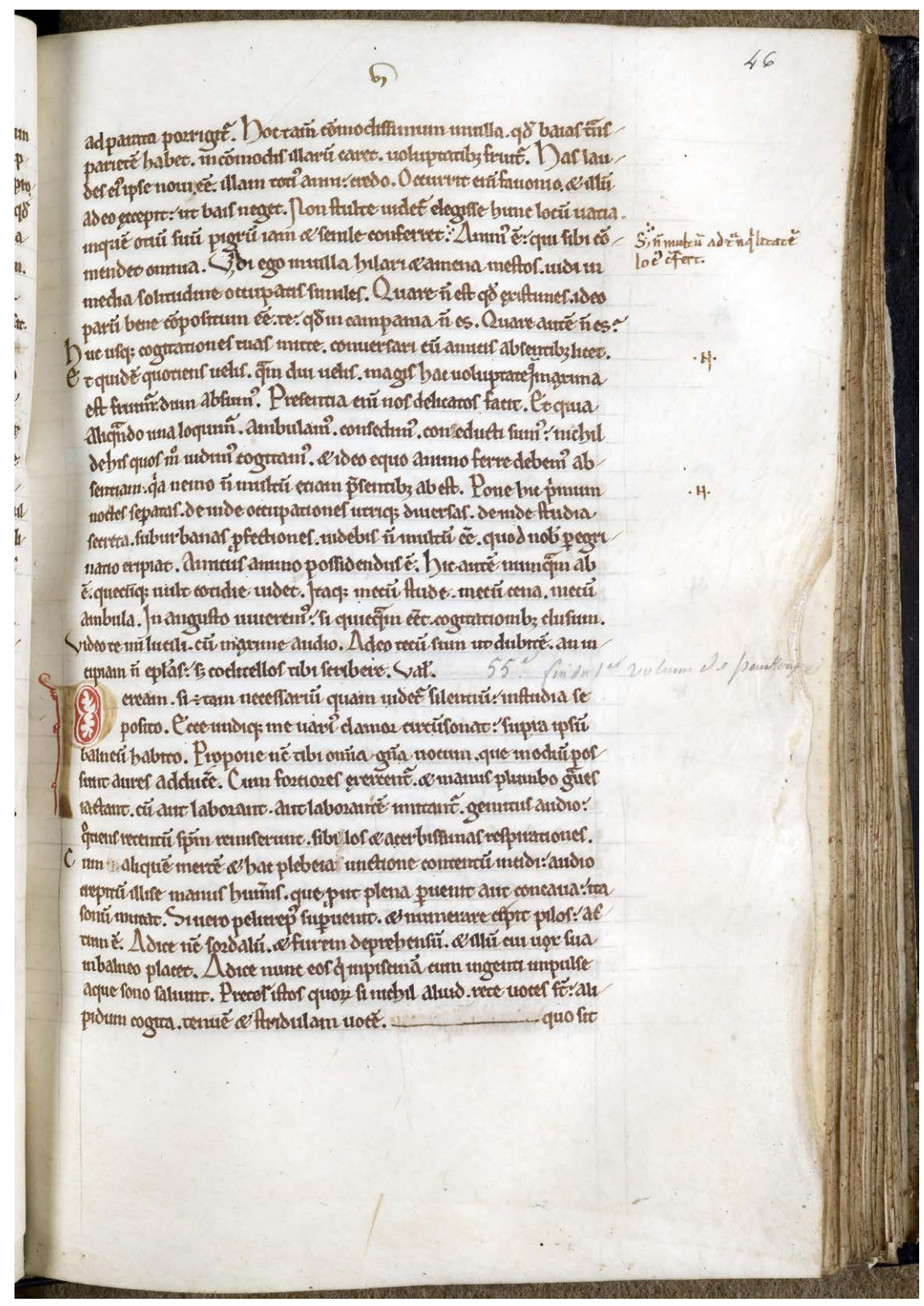

Pl. 6a: Avranches, Bibliothèque patrimoniale, ms. 239, fol. 46r 


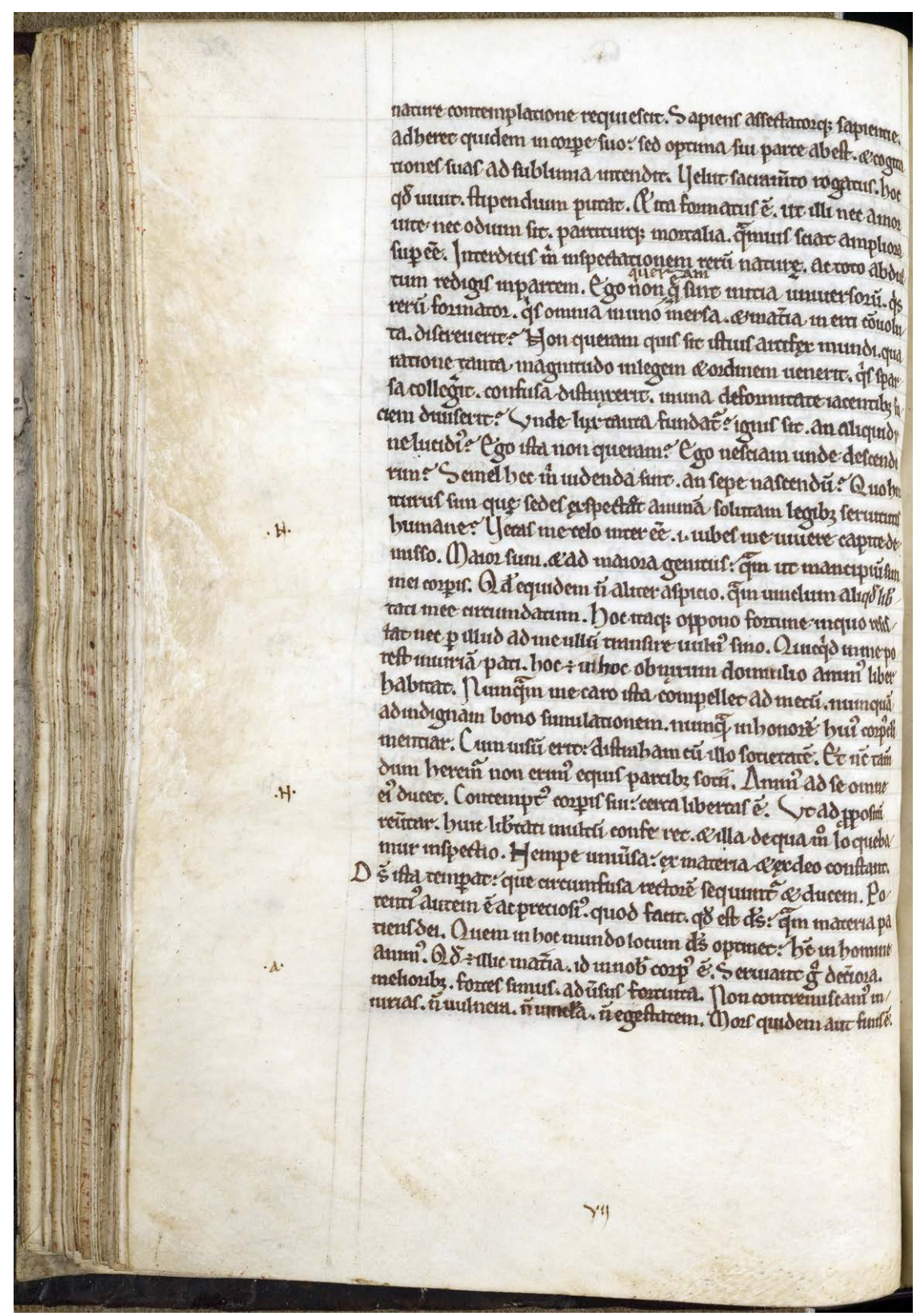

Pl. 6b: Avranches, Bibliothèque patrimoniale, ms. 239, fol. $56 \mathrm{v}$ 


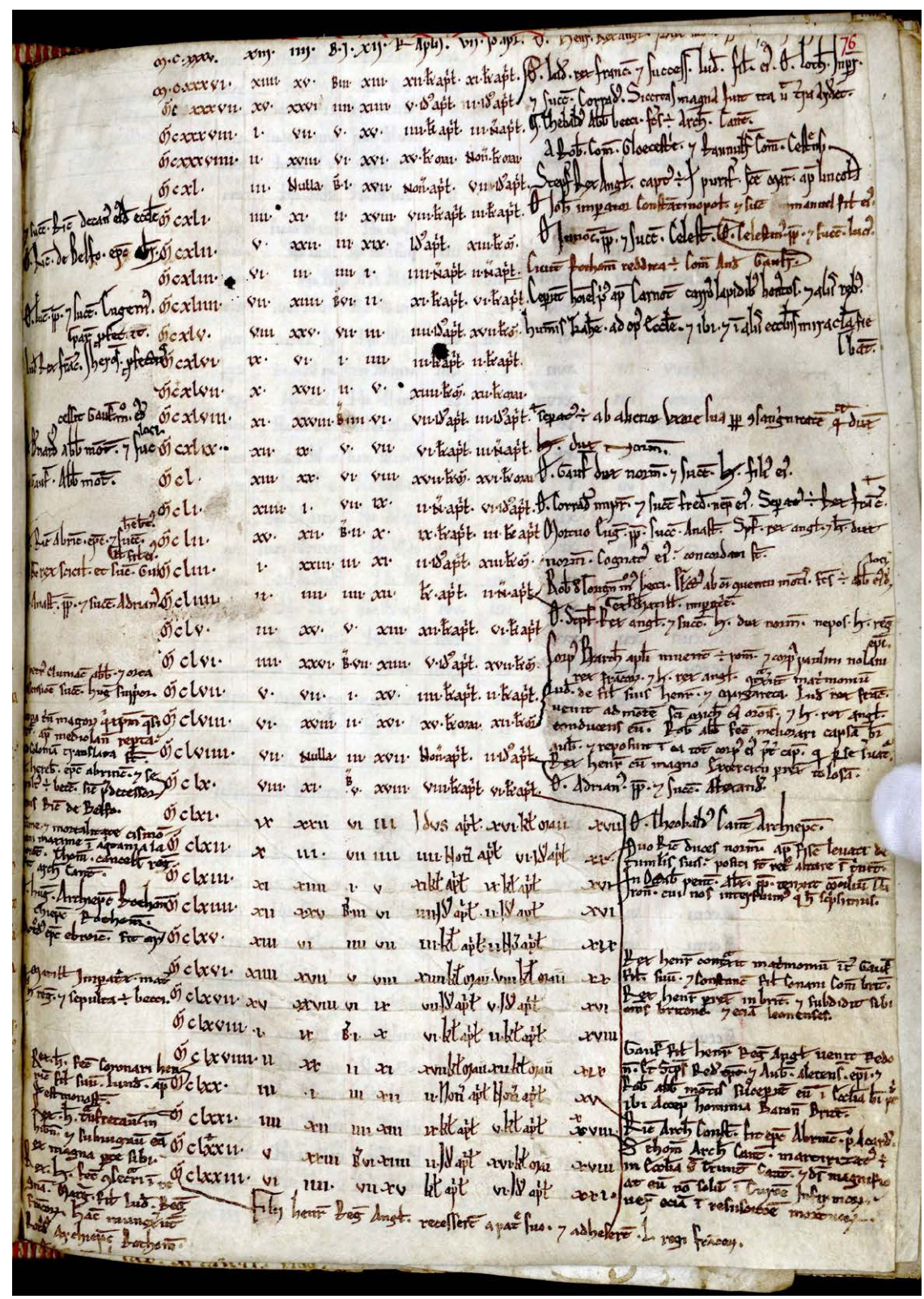

Pl. 7: Avranches, Bibliothèque patrimoniale, ms. 211, fol. 76r 


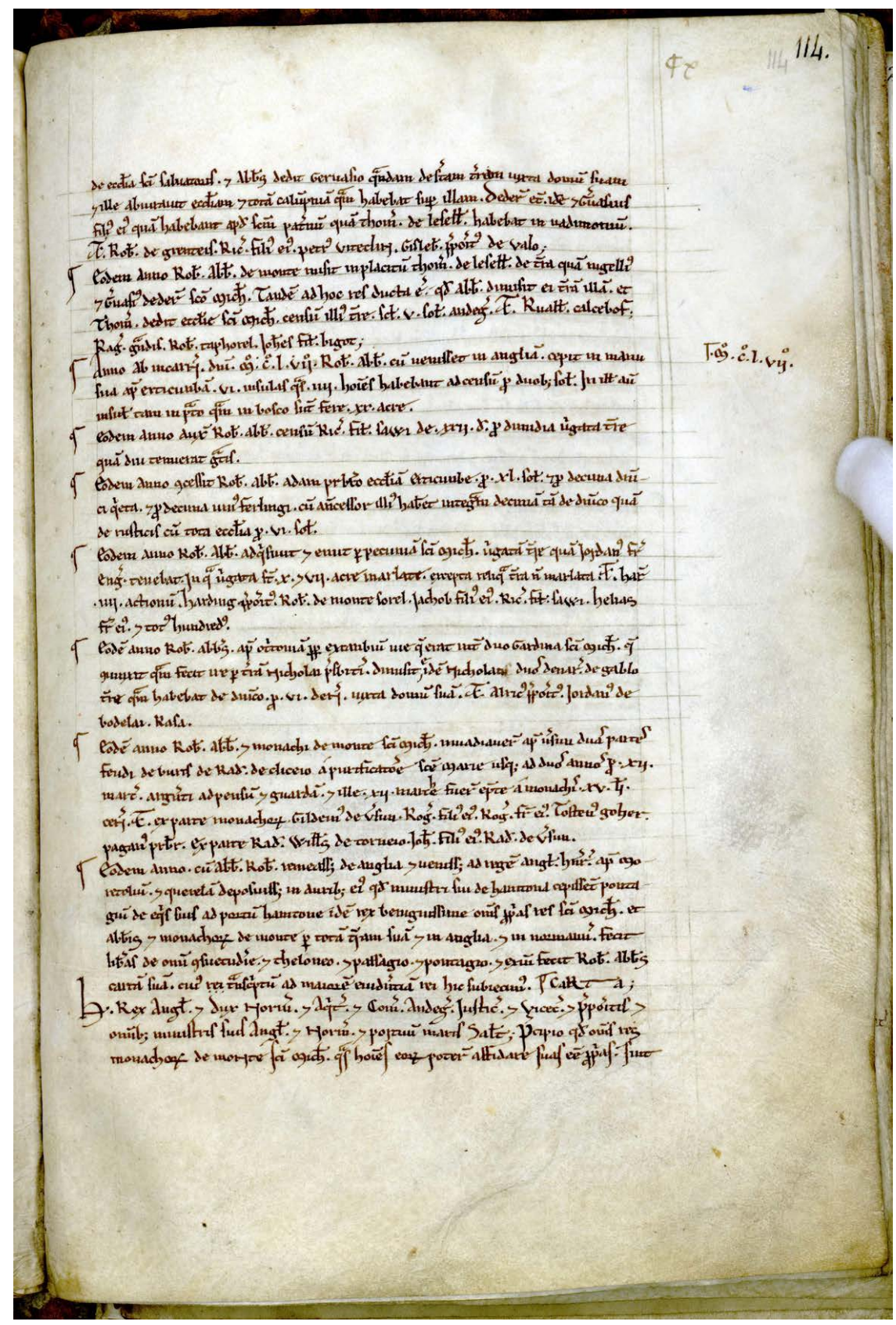

Pl. 8: Avranches, Bibliothèque patrimoniale, ms. 210, fol. 114r 


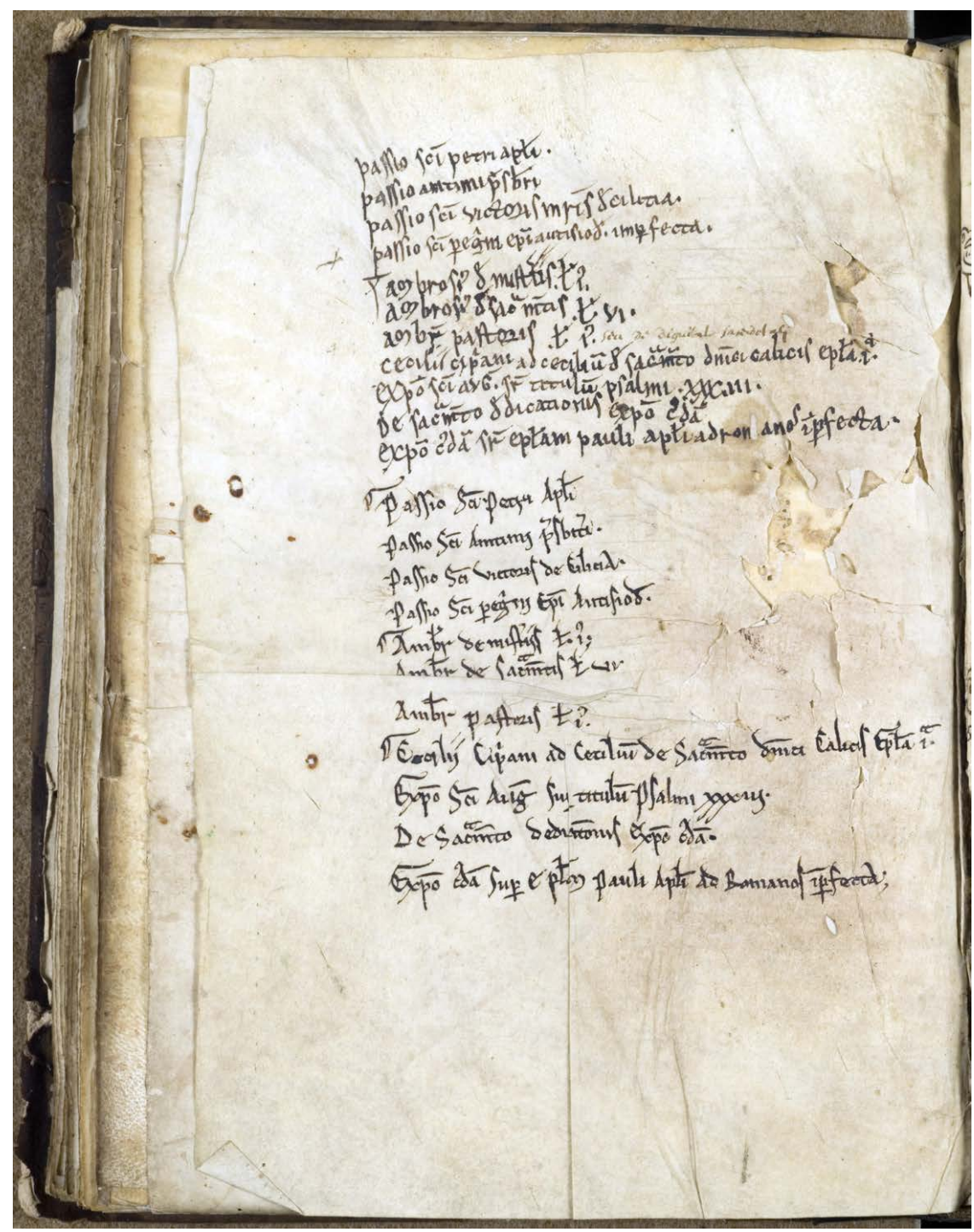

Pl. 9: Avranches, Bibliothèque patrimoniale, ms. 241, fol. 66v 


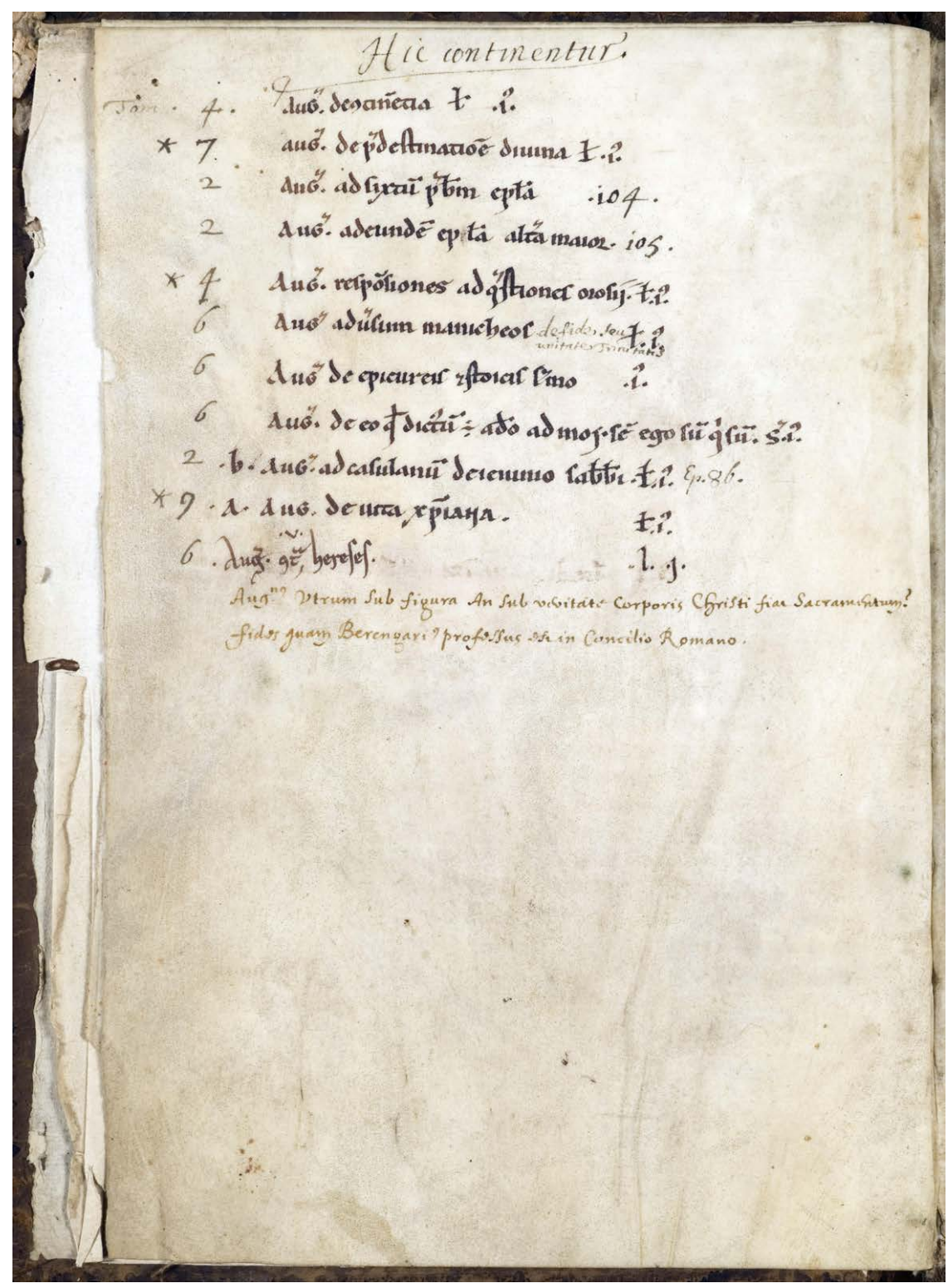

Pl. 10: Avranches, Bibliothèque patrimoniale, ms. 84, fol. 1v 


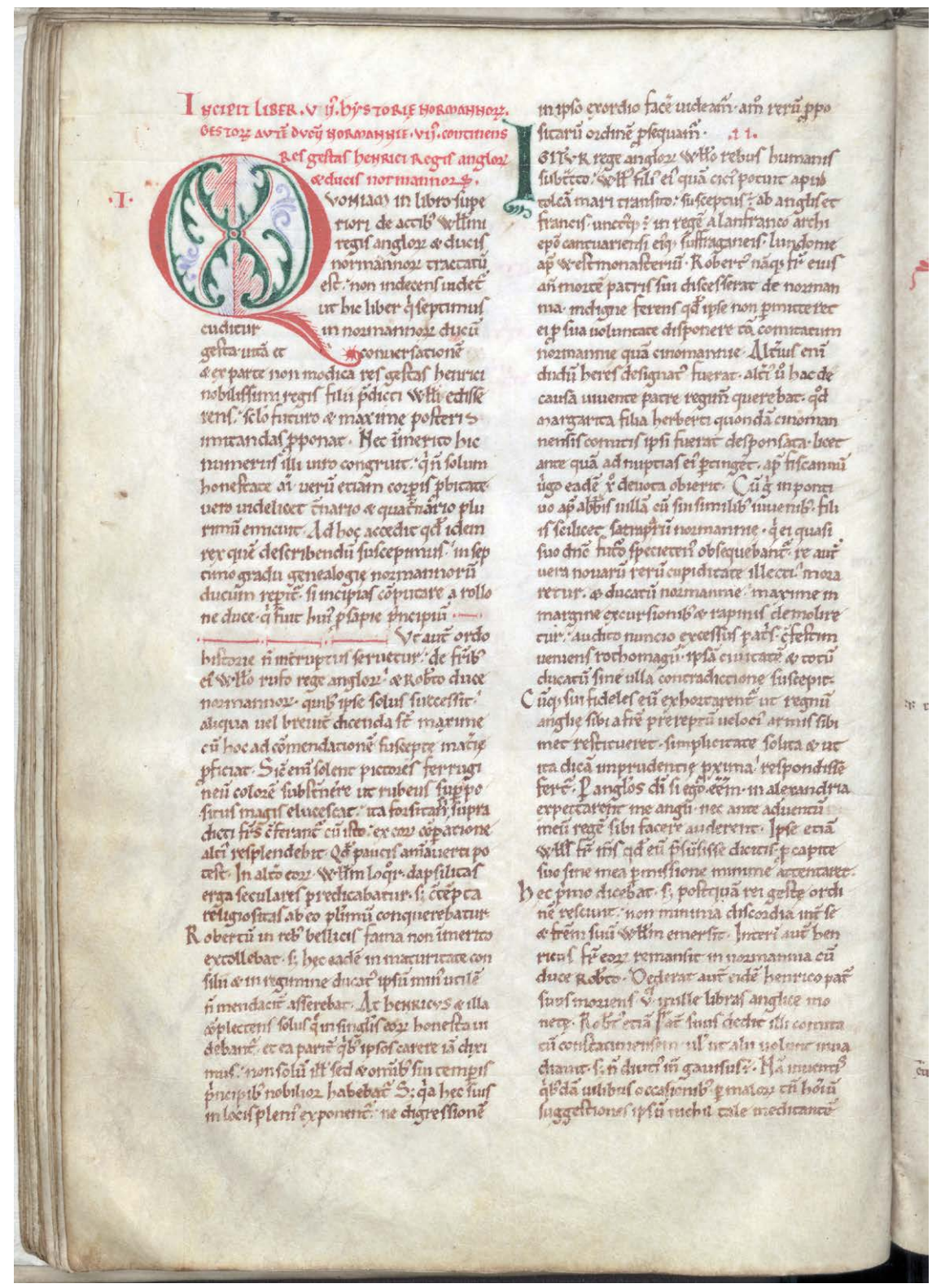

Pl. 11: Leiden, Universiteitsbibliotheek, ms. BPL 20, fol. 22V 


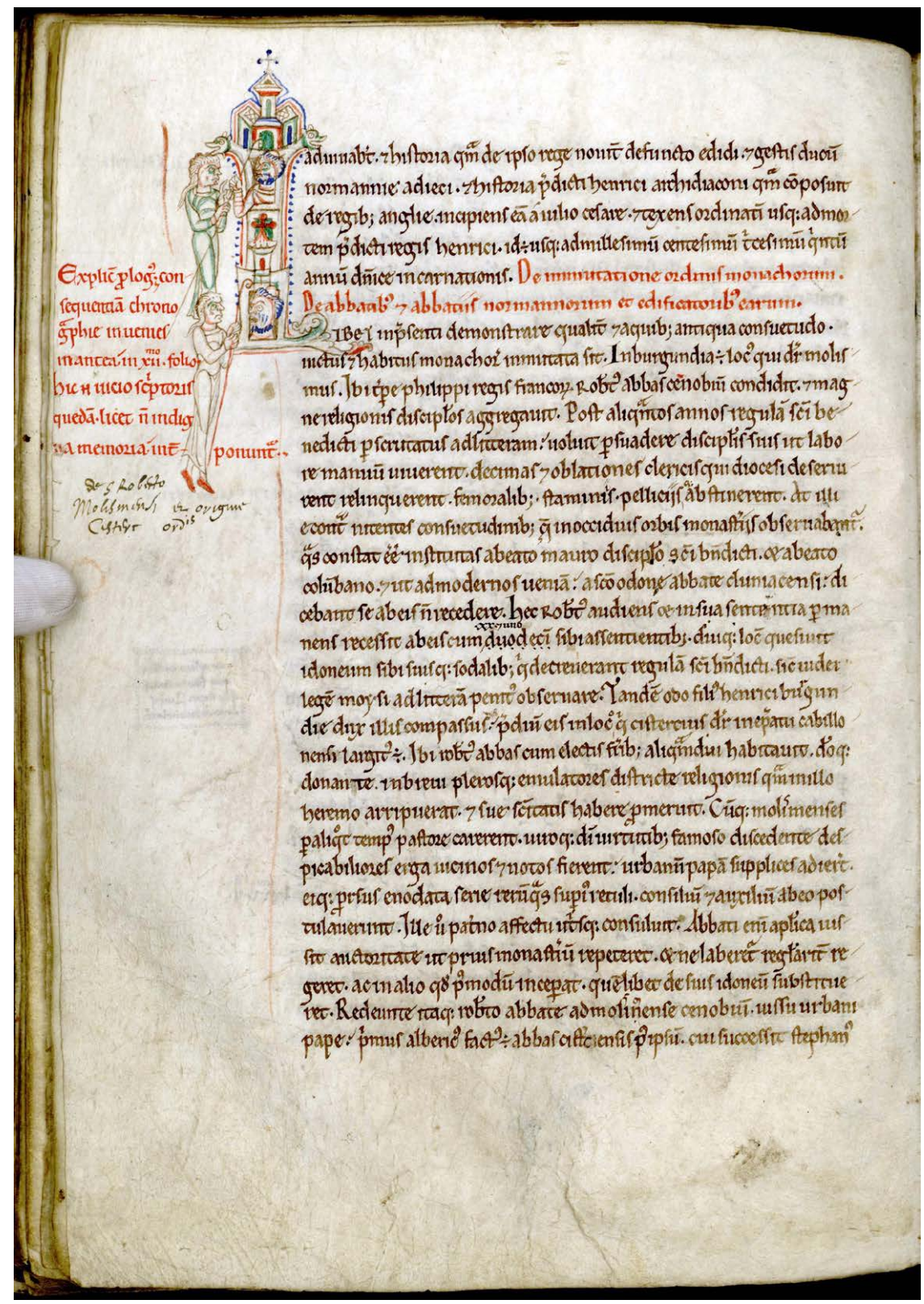

Pl. 12: Avranches, Bibliothèque patrimoniale, ms. 159, fol. 17ov 


\section{Bibliography}

\section{Manuscript}

Leiden, Universiteits bibliotheek, ms. BPL 20, fol. $4 \mathrm{r}$ Leiden, Universiteits bibliotheek, ms. BPL 2O, fol. 22V Avranches, Bibliothèque patrimoniale, ms. 159, fol. 53v Avranches, Bibliothèque patrimoniale, ms. 211, fol. 75V Avranches, Bibliothèque patrimoniale, ms. 146, fol. 165r Avranches, Bibliothèque patrimoniale, ms. 68, fol. Av Avranches, Bibliothèque patrimoniale, ms. 239, fol. 46r Avranches, Bibliothèque patrimoniale, ms. 239, fol. 56v Avranches, Bibliothèque patrimoniale, ms. 211, fol. 76r Avranches, Bibliothèque patrimoniale, ms. 210, fol. 114r Avranches, Bibliothèque patrimoniale, ms. 241, fol. 66v Avranches, Bibliothèque patrimoniale, ms. 84, fol. $1 \mathrm{v}$ Avranches, Bibliothèque patrimoniale, ms. 159, fol. 17ov

\section{Sources}

Bethmann, Ludwig C. (ed.), Sigeberti Gemblacensis chronographia, Hanover, Hahn (Monumenta Germaniae historica, Scriptores vi), 1844, p. 268-374.

Bisson, Thomas (ed. and transl.), The Chronography of Robert of Torigni, Oxford, Oxford University Press (Oxford Medieval Texts), 2020, 2 vols., in press.

Delisle, Léopold (ed.), Chronique de Robert de Torigni, abbé du Mont-Saint-Michel, Rouen, A. Le Brument, 1872-1873, 2 vol.

Howlett, Richard (ed.), "The Chronicle of Robert of Torigni, Abbot of the Monastery of St. Michael-in-Peril-of-the-Sea”, in Chronicles of the Reigns of Stephen, Henry II, and Richard I, Vol. IV, London, Eyre and Spottiswoode (Rerum britannicarum medii aevi scriptores, 82), 1889 (réimpr. Cambridge, Cambridge University Press, 2012).

\section{Bibliography}

BABсоCK, Robert Gary and Derolez, Albert, "The Gembloux scriptorium in the eleventh century", in Scriptorium. Wesen. Funktion. Eigenheiten, A. Nievergelt et al. (ed.), Munich, Bayerische Akademie der Wissenschaften, Verlag C.H. Beck, 2015, p. 259-274.

Bourgeois-Lechartier, Michel, “À la recherche du scriptorium de l'abbaye du Mont Saint-Michel”, in Millénaire monastique du Mont Saint-Michel, R. Foreville (dir.), Paris, P. Lethielleux, 1967 (Bibliothèque d'histoire et d'archéologie chrétiennes), t. 2, Vie montoise et rayonnement intellectuel, p. 171-202.

Brooke, Zachary N., The English Church and the Papacy from the Conquest to the Reign of John, new ed., Cambridge, Cambridge University Press, 1989 [1931]. 
Chazan, Mireille, L'Empire et l'histoire universelle. De Sigebert de Gembloux à Jean de Saint-Victor (XII ${ }^{e}-X I V^{e}$ siècle), Paris, Honoré Champion, 1999 (Études d'Histoire médiévale 3).

Cleaver, Laura, "The Monastic Library at Le Bec", in A Companion to the Abbey of Le Bec in the Central Middle Ages, B. Pohl and L. L. Gathagan (eds.), Leiden - Boston, Brill, 2018 (Brill's Companions to European History, 13), p. $171-205$.

Garand, Monique-Cécile, Grand, Geneviève et Muzerelle, Denis, "Ouest de la France et Pays de la Loire", in Catalogue des manuscrits en écriture latine portant des indications de date, de lieu ou de copiste, C. SAmaran and R. Marichal (eds.), Paris, Éditions du CNRS, t. 7, 1984.

Gullick, Michael, "Lanfranc and the Oldest Manuscript of the Collectio Lanfranci", in Bishops, Texts and the Use of Canon Law around 110o. Essays in Honour of Martin Brett, B. C. Brasington and K. G. Cushing (eds.), Aldershot, Ashgate Publishing, 2008 (Church, Faith and Culture in the Medieval West), p. 79-89.

Hermans, Jos M.-M. and van Houts, Elisabeth M. C., "The History of a membrum disiectum of the Gesta Normannorum Ducum, now Vatican, Reg. Lat. 733 fol. 51", Mededelingen van het Nederlands Instituut de Rome / Papers of the Dutch Institute in Rome, NS 9/10 (1982-1983), p. 79-94.

Lecouteux, Stéphane, “Écrire l'histoire des abbés du Mont Saint-Michel. 2. Robert de Torigni, ses outils, ses sources et sa méthode de travail", Tabularia [Online], Sources en ligne, URL: http://journals.openedition.org/tabularia/2973.

Nortier, Geneviève, Les bibliothèques médiévales des abbayes bénédictines de Normandie: Fécamp, Le Bec, Le Mont Saint-Michel, Saint-Evroul, Lyre, Jumièges, Saint-Wandrille, Saint-Ouen, Caen, Caron et cie, 1966.

PoHL, Benjamin, "Abbas qui et scriptor? The Handwriting of Robert of Torigni and his Scribal Activity as Abbot of Mont-Saint-Michel (1154-1186)", Traditio, 69, 2014, p. 45-86.

PoHL, Benjamin, “When Did Robert of Torigni First Receive Henry of Huntingdon's Historia Anglorum, and Why Does It Matter?", The Haskins Society Journal 26-2014, Studies in Medieval History, 2015, p. 143-168, URL: http://www.jstor.org/stable/ 10.7722/j.ctt17mvjs6.11.

Pohl, Benjamin and Gathagan, Laura L. (eds.), A Companion to the Abbey of Le Bec in the Central Middle Ages, Leiden - Boston, Brill, 2018 (Brill's Companions to European History, 13).

WebBer, Teresa, Scribes and scholars at Salisbury cathedral c. 1075-c. 112, Oxford, Clarendon Press, 1992 (Oxford Historical Monographs). 